\section{（神奈川 山本洋一）}

\section{答}

生殖腺線量は散乱線によりますが，管電庄が高くなる ほど，X線照射時間が短かくなり，管電圧に比例して線 量は減少する.

\section{DIC 法による胆管造影法の検討}

大阪市立住吉市民病院

○田淵 良雄・竹森 賢吾・英加富士男 胆道系の造影法として, 今回 DIC 法により造影率等 の検討をおこなった。

[検査の対象]

経口法，経静脈法，並用法により胆露，胆管の造影不 良のもの.

[方法]

$\mathrm{A}$ 群 5\% ブドウ糖液 $80 \mathrm{cc}+30 \%$ ビリグラフィン $60 \mathrm{cc}$ を 30 ４0分で点滴，B群 $5 \%$ クリニット $150 \mathrm{cc}+30 \%$ ビリ グラフィン $60 \mathrm{cc}$ を 50 ６0分で点滴．点滴開始 30 分より 10 分間隔で 120 分まで撮影。体位は背臥位第 2 斜位.

\section{[造影成績]}

胆管の明膫に造影されたものA群 $49.7 \% ， \mathrm{~B}$ 群 $54.0 \%$ 。 最高濃度は点滴開始後60～90分にみられた。

〔副作用〕

点滴時間50〜60分では少い.

\section{〔結論】}

入院患者は病室，外来患者は別室にて50～60分で点滴 終了させるととにより，長時間撮影室を独占しないで撮 影できる.

\section{座長集約}

胃・十二指腸とむに被写体の動きによるボケを無くす る為, 撮影の曝射時間の短縮が再検討された，大容量装 置高性能X線管の設置が可能なれば容易な問題であろう が. 胆道系造影法として最近，腎孟造影と並んで点滴法 が検討されはじめているが，討論が充分尽され得なかっ たのは心残りである.従来より行われている経口造影, 経静脈造影法と基本的な撮影法に大差は無いように思的 れる.ただ，造影される時間的な撮影タイミングは今後 あ検討されよう．他の演題にあ共通している問題である が，研究者には，少くとも過去 2 3 年の関連研究報告 には目を通していただく事を希望したい。

ての演題群に関し，医学診断域にまで入りすぎてはな いか，技術学会では医学の内のどの辺りまで討論の対象 とするのか，技術学之は何か，との疑問が生じて来るよ うである．確かに発表内容には医師の口にすべきすの， 医師の手でしか出来ない事が研究の中に存在している.
とこで現在の技術学会をみるに，学会は支部組織を持っ ている．乙の辺りの混乱はあろうが技術学会員たるべき 者の身分，資格汇関する制限は無く，放射線技術に関連 するむのが加入出来るシステムをとっている．したがっ て研究発表をしようとする者が放射線技師とは限らない であろう。乙れが疑閣に対する回答の一つとなるであろ う，さらに，技術学会で発表されようとするすのが，臨 床の場で医療の為に考案された結果であったり, 診療に 際し放射線を利用した情報収集の正当な研鑚の過程であ れば，公表の場として技術学会を求められれば門戸を広 く開けてあよろしかろうと考える，学問の場で妙な領域 を設けたり，設けようとする事が妙である．とりわけ医 橑診断学に関して神経過敏の妙䢃を持つきらいがある。 医療に貢献すべき放射線技術が，基礎医学を避け或いは， いたずらに何かをおそれて避けていたのでは，医療の中 における放射線技術学の発展はあり得ないであろう。発 展の糧としてむしろ進んで医学の基礎を己があのとし， それに立脚した放射線の利用をしててそ技術であり，技 術学というものではなからうか. 疑問に応じられる二つ めである.

ただ，䦓題となるべきは医師で無い者が，技術学を学 んだ結果，医学の一面を知り偽医師的な行為をとる場合 にのみ問題があり，社会的背任行為となる事の限界を自 覚せ补ばならない事である。乙の限界が確認出来るもの であれば，場違いとの疑問そのあのが無意味とは考えら れないだろうか。

一部は総会場にて質間に対し応え，簡単汇再整理して みた次第である，技術学というあのがどの辺りで，どの 様に確立されるかは確か机判別出来か杍るが，身近か门 存在する日本放射線技術学会にこの問題を仲立, 提起し 前進のズテップとしたい．尚，別項の如き要望を即日， 学会長に提出した事を併記して座長総括としたい.

[学会えの要望のとと]

4 月 4 日, 胃・十二指腸・胆のう造影撮影䎲関する撮 影(8)゙ループの討論中，会員より下記の如き質疑があり 問題が提起されました。

「現在，学会とは如何䎲あるべきか。技術学とは何か という問題が学会本部で検討されている．その時，ての 演題グループの中には技術学とは何かというテーママに対 して疑問を感じさせる演題内容が数題含まれている。 今 後の技術学の確立のために座長見解を間う」

私見と致しまして簡単ではありましたが,

「既存概念からすれば，胆のう等の藏器造影撮影の場 合は技術学会で取扱う分野と医学会で取扱われるである う分野の接点に位置するテーマと考える．患者を中心と 
する医療を考元る場合，患者に対して㟝断治療を行う医 師に対し，可能な限りの情報を提供されるべきは当然の 事であり，その一部を分担する技術者等が患者に対し， 直接，診断等を言及するのではなく，医師に対して情報 を提供するのであれば，その研究内容を当技術学会で発 表しようとするのは，技術学会の場にのせて然るべきで あると考える．以上の考えより研究者には第27回日本放 射線技術学会にて研究発表を行っていただいた次第であ る」

として;一与えられた時間の関係もあり，提起された問 題は大変重要な問題点を持つ内容で，一座長の私見のみ に終らせず学会の問題点として取り上げていただくよう 学会本部に座長より要望する事にして質問者ならびに学 会出席者の諒解を求めた次第です.

一座長の見解のみにて終らすべき問題ではないと考元， 前記の提起さた問題点に関し，何らかの方法・手段によ り，学会としての見解を集約され，会員に対しその見解 を早急に示される事を要望し，お願い申し上げる次第で あります。

\section{日本放射線技術学会 \\ 石 田 勝 哉会長殿}

\section{X-TV 1 座長 福田 徹夫}

55. X線テレビ装置における NC 回路使用の自動化に $\supset$ つて

$$
\begin{aligned}
& \text { 田中レントゲン製作所埼玉工場 } \\
& \text { ○宮崎 博二・山本 義人 } \\
& \text { 矢野 太・橋口不可止 }
\end{aligned}
$$

\section{6. 間欠 X線パルス TV 透視法について（第2 報）}

長崎大学病院

高尾 義人

本方式を立体テレビ透視に用い，左眼又は右眼用の内 片方のモニターに第1フィールドが出ている時期に他の モニターに第 2 フィールドを出す方式とすれば，第 1 第 2 フィールド間のフリッカーを消去出来ると共に両方の モニターにそれぞれ1フルームづつの完全面像を出す事 が出来る為立体透視の画質の改良も出来る. 又パルス透 視法はスイッチで任意の時期に 1 回づつパルスX線を照 射して長時間画像を固定して出せるが，1 パルスの照射 線量は 0.5 乃至 $1.0 \mathrm{mR}$ 程度であるから，との方法を視 束撮影その他位置定めの因難な撮影前の透視に用いれば, 被検者のX線被嚗量をほとんど堌加させず正確な位置定 內を確認して1回で確実な写真が撮影出来る. 更にての 時のパルスX線照射を利用して被写体のX線透過度を正
確に計測して撮影条件を算定する事す可能となる等の効 果を期待出来る.

\section{7. 磁気記憶式透視 X線量低減システム（技術的諸問 題の検討）}

\author{
日立レントゲン株式会社柏工場 \\ ○矢仲 重信 \\ 長崎大学㗨学部放射線科 \\ 高尾 䉝人
}

\section{質問}

$\mathrm{X}$ 線パルス間欠ばく射15回毎秒の場合の場合の被ばく 低滅率 $32 \%$ とのととですが，その時の間欠ばく射条件と 比較した普通透視の条件はそれぞれぞのようになってい るか。電圧 $80 \mathrm{kVp}$

$\left.\begin{array}{ll}\text { 間欠ばく射条件 } & \left\{\begin{array}{l}\text { 何 } \mathrm{mA} \\ \text { 何 } \mathrm{mS} \\ \text { 普通透視条件 }\end{array} \text { 何 } \mathrm{mA} \text { 連続 }\right.\end{array}\right\}$ とを比較

答

（大分．野田一郎）

パルスX線の条件は，電流 $15 \mathrm{mAp}$ パルス幅は $2 \mathrm{~ms}$ で ある。

58. 4 吋撮影管アインコンを用いたロールフィルム方 式 $X$ 線 TV 装置について

大阪府立成人病センター放射線部 ○日浦 康雄・松田一 二宮 警·吉田 次郎 島津製作所 高尾 茝美

[目的〕

わが国で始めてあらゆるX線検査に使用出来るように 大陸判ロールフィルムに 12.5 时の螢光板に超高感度 4.5 吋イメージアイソコンを用いたX線 TV 装置を設計製作 する。

[機構と機能]

$\mathrm{TV}$ 関係では走查線数が 841 本，又暗部での $\mathrm{S} / \mathrm{N}$ が 改善されている．撮影系では口ールフィルムチェンジャ 一を設え 14 时巾長さ $25 \mathrm{~m}$ 迄のフィルムが収納出来る．X 線管の傾斜角度は透視台長手方向に $\pm 35^{\circ}$ に亘る角度で 撮影が可能である.イオントマットを用いたオートショ ット方式である. 二重圧迫筒を設え一般圧迫の他倍部分 圧迫汃行兑る。

以上の機能より従来の XTV より解像度が良く, 又視 野が広くハレーションを起しにくく, より多くのX線検 查に使用が可能である.

質問 